\title{
Rock Mass Grouting in the Løren Tunnel: Case Study with the Main Focus on the Groutability and Feasibility of Drill Parameter Interpretation
}

\author{
Are Håvard Høien • Bjørn Nilsen
}

Received: 29 June 2012/ Accepted: 1 February 2013/Published online: 21 February 2013

(C) The Author(s) 2013. This article is published with open access at Springerlink.com

\begin{abstract}
The Løren road tunnel is a part of a major project at Ring road 3 in Oslo, Norway. The rock part of the tunnel is $915 \mathrm{~m}$ long and has two tubes with three lanes and breakdown lanes. Strict water ingress restriction was specified and continuous rock mass grouting was, therefore, carried out for the entire tunnel, which was excavated in folded Cambro-Silurian shales intruded by numerous dykes. This paper describes the rock mass grouting that was carried out for the Løren tunnel. Particular emphasis is placed on discussing grout consumption and the challenges that were encountered when passing under a distinct rock depression. Measurement while drilling (MWD) technology was used for this project, and, in this paper, the relationships between the drill parameter interpretation (DPI) factors water and fracturing are examined in relation to grout volumes. A lowering of the groundwater table was experienced during excavation under the rock depression, but the groundwater was nearly re-established after completion of the main construction work. A planned 80-m watertight concrete lining was not required to be built due to the excellent results from grouting in the rock depression area. A relationship was found between leakages mapped in the tunnel and the DPI water factor, indicating that water is actually present where the DPI water factor shows water in the rock. It is concluded that, for the Løren tunnel, careful planning and high-quality execution of the rock mass grouting made the measured water ingress meet the
\end{abstract}

\footnotetext{
A. H. Høien ( $\square)$

Norwegian Public Roads Administration, Postboks 8142 Dep, 0033 Oslo, Norway

e-mail: are.hoien@vegvesen.no

B. Nilsen

Norwegian University of Science and Technology,

Sem Sælands veg 1, 7491 Trondheim, Norway
}

restrictions. For future projects, the DPI water factor may be used to give a better understanding of the material in which the rock mass grouting is performed and may also be used to reduce the time spent and volumes used when grouting.

Keywords Rock mass grouting · Grouting procedures · Groundwater · Fracturing · Measurement while drilling · MWD · Drill parameter interpretation · DPI

\section{Introduction}

Tunnelling in urban areas involves many challenges. One of the biggest challenges is the risk of lowering the groundwater table, which may harm buildings and the environment. Urban tunnels usually have strict water ingress restrictions and systematic pre-grouting of the rock mass is usually described. In these cases, the rock mass grouting is a major part of the construction process and must be given great attention in the planning and execution phases in order to obtain a satisfactory result. In this paper, the typical challenges of such projects will be discussed based on the experiences from rock mass grouting in the Løren road tunnel, which is presently under construction in Oslo, Norway (see Fig. 1).

The rock part of the Løren tunnel is $915 \mathrm{~m}$ long (see Fig. 2). The tunnel has two tubes with three lanes and breakdown lanes, which results in face areas of 105-135 $\mathrm{m}^{2}$. The tunnel is excavated from one side by drill and blast technology and continuous grouting. Tube B is excavated approximately $30 \mathrm{~m}$ ahead of tube A on descending profile numbers. In the area above the tunnel, there is a mix of residential and commercial buildings founded on soft, sensitive clay and sandy, gravelly soil, with a thickness of up to 
$30 \mathrm{~m}$. Strict water ingress restrictions from 7 to $101 / \mathrm{min} /$ $100 \mathrm{~m}$ were, therefore, given.

This article will describe the rock mass grouting that has been done for the Løren project and present some issues and findings which are believed to be of particular interest.

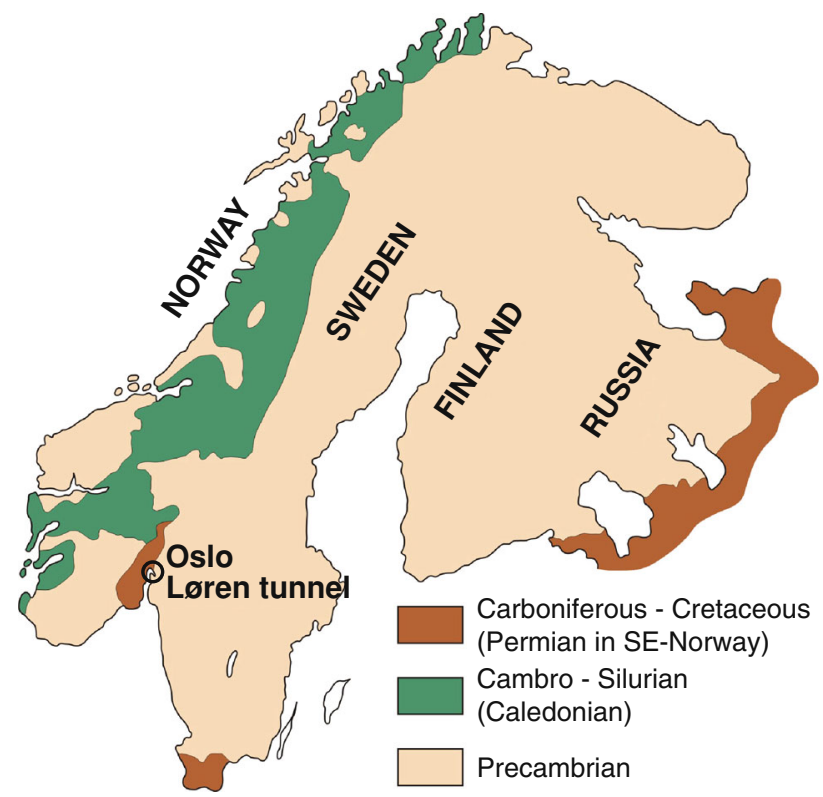

Fig. 1 Location of the Løren road tunnel, Oslo, Norway
One such issue is groundwater and grouting aspects of the excavation under a depression with low rock overburden below $30 \mathrm{~m}$ of soil. Another issue which is discussed in more detail is the use of drill parameter interpretation (DPI) and its possible use for grouting purposes.

DPI is a new, innovative system for logging boreholes (measurement while drilling, MWD) and interpretation of these logs into factors that describe the rock mass. The DPI system at the Løren tunnel provided three factors: hardness, fracturing and water.

The main objectives in the following are, thus:

- To describe the geological and hydrogeological characteristics and the grouting procedures for the Løren tunnel.

- To describe the grouting results: in general, in relation to the rock depression and in relation to the grout consumptions.

- To describe the relationships between DPI water and fracturing factors and grout volumes

\section{Ground Conditions and Grouting Procedure for the Løren Tunnel}

The Løren tunnel is situated in a developed area with a mix of residential and commercial buildings. The residential

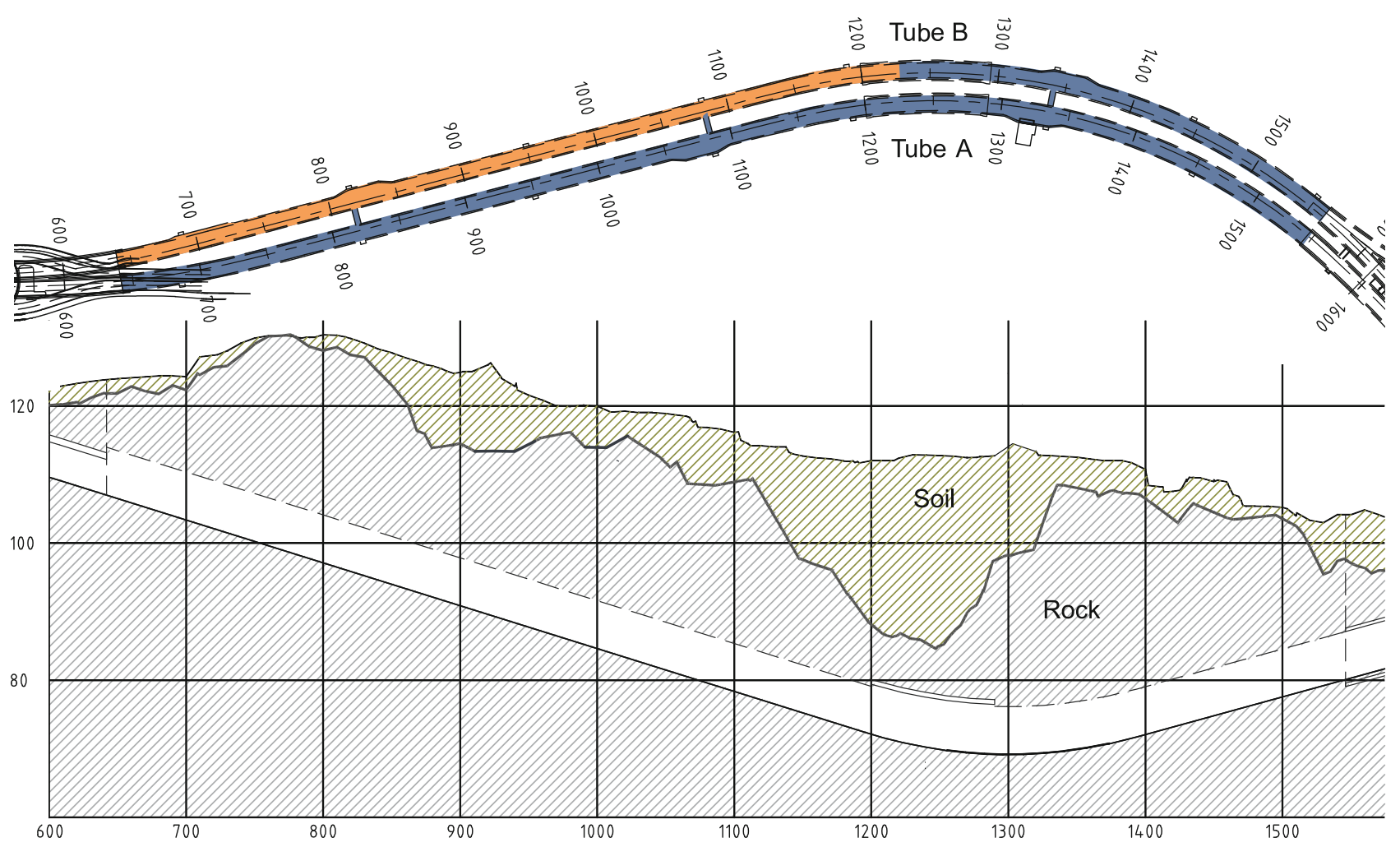

Fig. 2 Plan view and longitudinal profile of the Løren tunnel. The coloured areas on the plan view are the rock parts of the tunnel. The orange area is the section in focus on this article regarding drill parameter interpretation (DPI) and grout volumes 
buildings are mostly 1-2-floor townhouses or single-family houses constructed from wood and some larger concrete constructions with 4-7 floors. The commercial buildings are concrete constructions with 4-6 floors. An assessment of the potential settlement caused by lowering the groundwater level that could damage these buildings was, therefore, performed. During the pre-investigations, a large number of ground investigation boreholes were drilled to establish a theoretical rock surface and soil profiles. Observation wells were also established to survey the groundwater over time.

\subsection{Ground Conditions}

\subsubsection{Soil and Rock Overburden}

Throughout the tunnel, the rock overburden was mostly satisfactory, except for an area between profile nos. 1150-1300, where the rock surface has a depression as shown in Fig. 2. Due to alignment restrictions at the start and end point of the tunnel and road gradient restrictions, the rock overburden in this area was only $6-8 \mathrm{~m}$ for a $50-\mathrm{m}$ stretch.

The soil cover in the same area was approximately $30 \mathrm{~m}$, with 3-5-m-thick dry crust clay on top of soft, sensitive clay, with sandy, gravelly soil at the bottom
8-10 $\mathrm{m}$. This makes the area sensitive for settlement in case of lowering the groundwater level (Henriksen and Føyn 2004).

\subsubsection{Groundwater}

Before and during construction, 20 observation wells with automatic logging surveyed the groundwater level in the influential area for the tunnel. To obtain the seasonal and yearly variations in the groundwater levels, these wells had approximately 3 years of logging before the construction started. A few other wells had data from 5 years ahead of construction commencement. The long-term logging is important as a background when evaluating groundwater levels during construction.

Prior to the excavation, one infiltration well was established from the surface in the area mentioned above. In addition, in the same area, two infiltration holes were drilled during excavation from each of the tunnel tubes. These two holes were drilled along the tunnel axis with a small angle away from the tubes.

\subsubsection{Bedrock Geology}

During excavation, an engineering geologist mapped the geology, as illustrated in Fig. 3, and estimated a $Q$ value
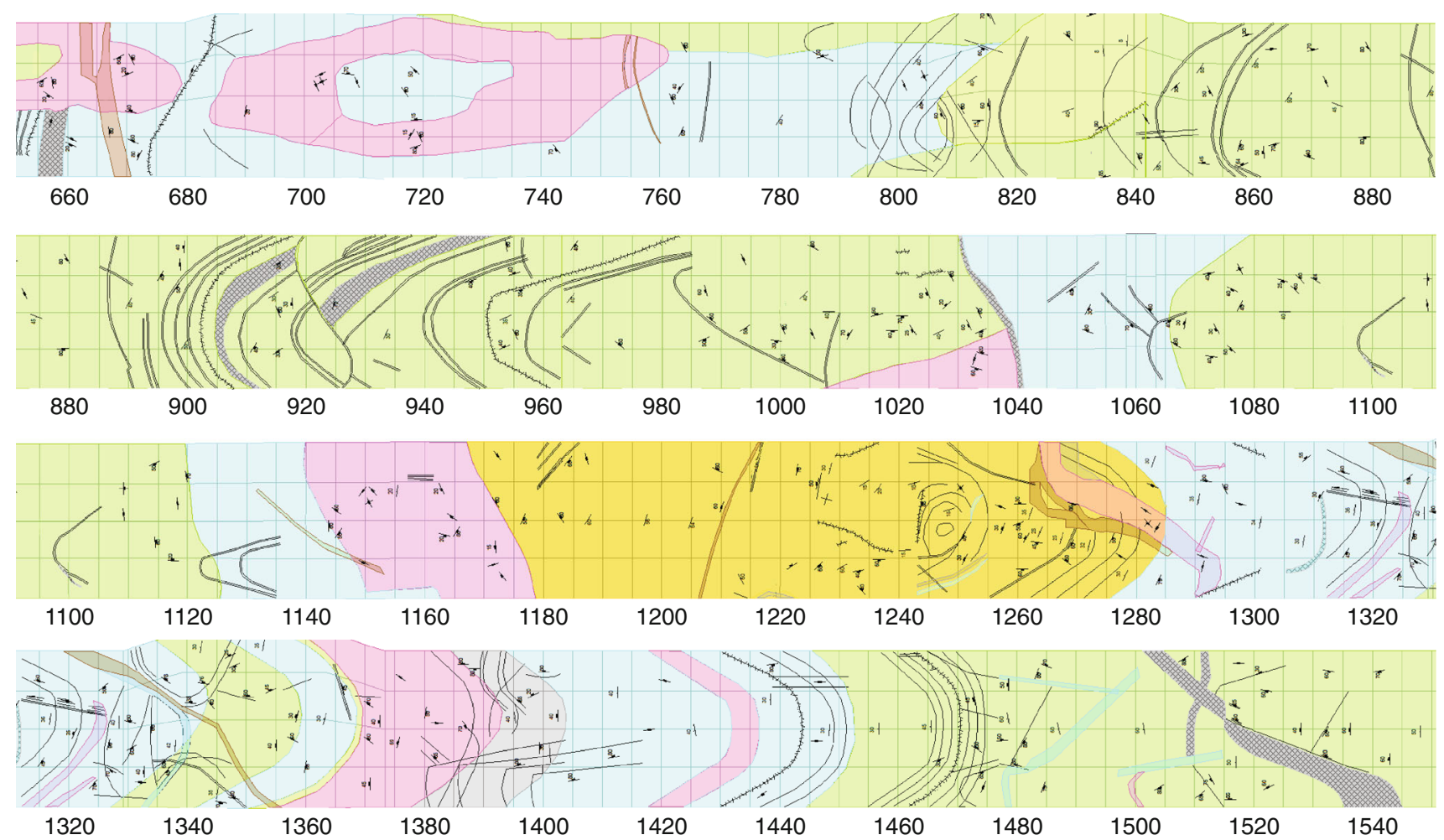

Fig. 3 Tunnel geology based on blast round mapping. The map is drawn as a fold-out tunnel profile. The rock types represented by the different colours are explained in Table 1. The black lines represent major joints and faults/weakness zones 


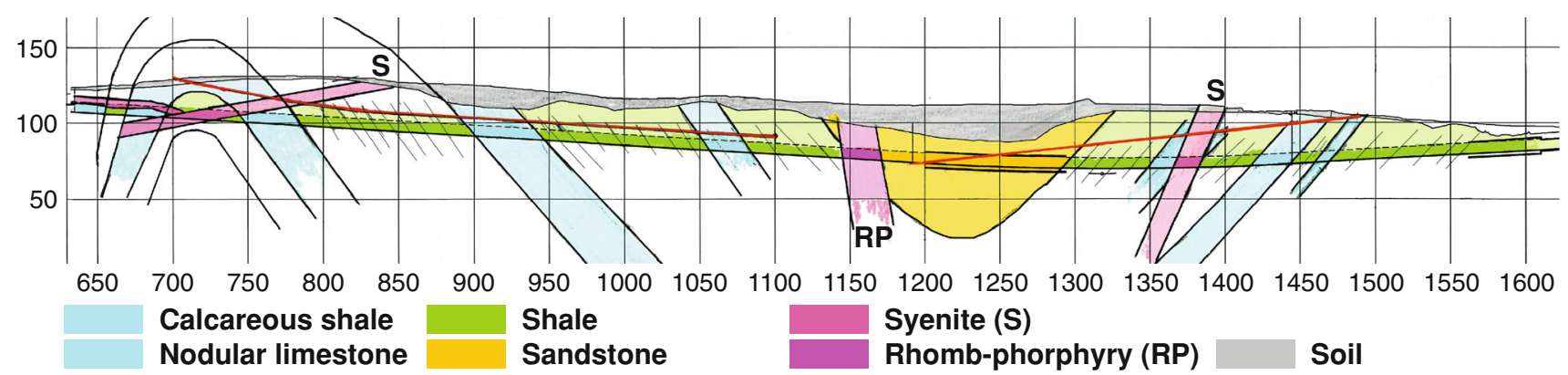

Fig. 4 Longitudinal profile illustrating the rock type distribution and structural geology (Iversen 2011)



Fig. 5 Typical geology of sedimentary rocks. Shale and bentonite rock at profile no. B952

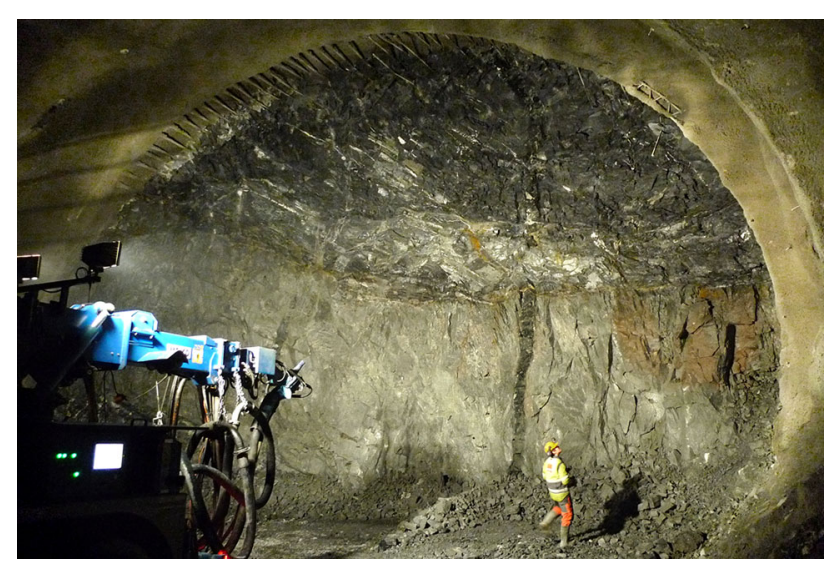

Fig. 6 Typical geology of intrusions. Sub-horizontal syenite intrusion and steep diabase dyke in sandstone (top) at profile no. A1239

after each blast. The geology information was registered in a tunnel documentation software called Novapoint Tunnel (Vianova 2011) on a fold-out tunnel profile (Humstad et al. 2012). A geological longitudinal section map as shown in Fig. 4 was made based on this mapping and the pre-construction investigations.

The geology in the area, as shown in Fig. 1, is related to the Oslo Graben system of Cambrian, Ordovician and
Table 1 Tunnel geology

\begin{tabular}{lll}
\hline From & To & Geology \\
\hline B1560 & B1445 & Shale \\
B1445 & B1425 & Calcareous shale \\
B1325 & B1420 & Syenite \\
B1420 & B1395 & Nodular limestone \\
B1395 & B1380 & Black shale \\
B1380 & B1355 & Syenite \\
B1355 & B1340 & Nodular limestone \\
B1340 & B1325 & Shale, diabase \\
B1325 & B1275 & Alternating nodular limestone and black shale, \\
& & diabase and syenite \\
B1275 & B1175 & Sandstone, diabase and syenite \\
B1175 & B1145 & Rhomb-porphyry \\
B1145 & B1120 & Nodular limestone \\
B1120 & B1070 & Shale \\
B1070 & B1040 & Nodular limestone \\
B1040 & B980 & Shale, with a small fault and syenite at B1040 \\
B980 & B885 & Shale, with layers of bentonite rock \\
B885 & B810 & Shale \\
B810 & B640 & Calcareous shale with syenite in the tunnel roof \\
\hline
\end{tabular}

Silurian age. The rock types mapped in the tunnel are sandstones, calcareous shale, black shale, nodular limestone and intrusions of rhomb-porphyry, diabase and syenite. Details regarding the geology and rock type distribution along the tunnel are shown in Figs. 3, 4, 5 and 6 , and Table 1.

\subsubsection{Weakness Zones and Fractures}

The tunnel has intersected several minor faults/weakness zones, as shown in Fig. 3. Generally, the boundaries between sedimentary rocks and syenite/rhomb-porphyry are weaker than the surrounding rock. Weakness zones from profile nos. 900-990 in Fig. 3 are layers of bentonite rock which crack/disintegrate in contact with water.

The degree of fracturing along the tunnel, as mapped after each blast round, was mainly moderate (RQD mainly 


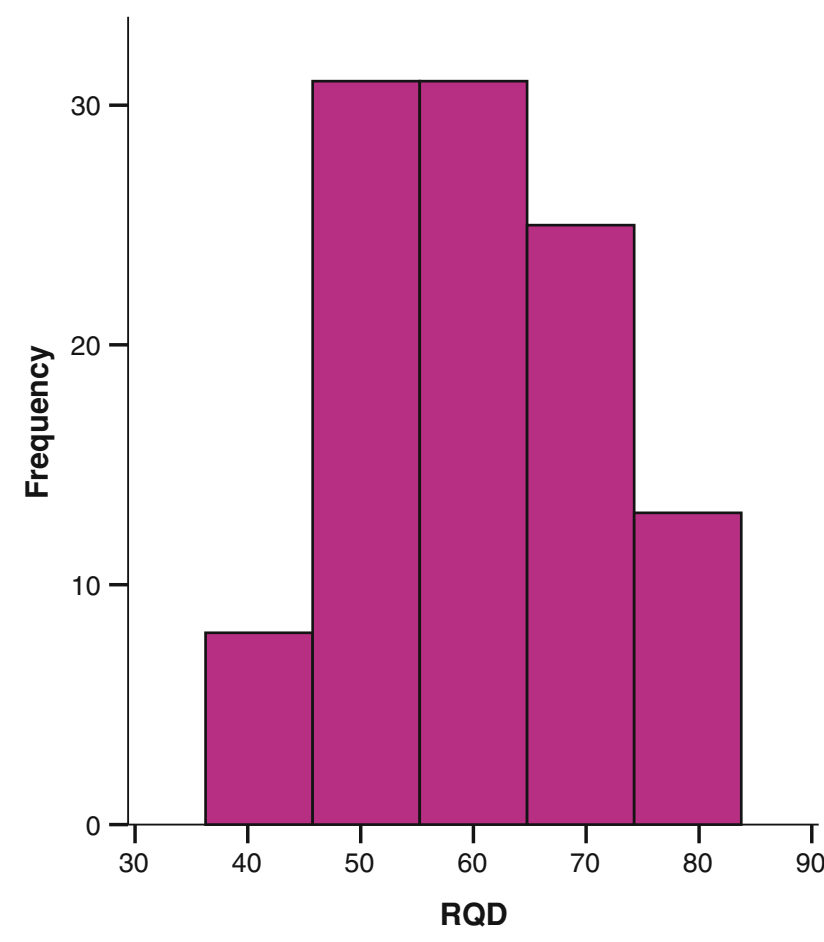

Fig. 7 Fracture frequencies (RQD) from $Q$ value mapping during excavation

within the range 50-70), but with some variation, as illustrated in Fig. 7.

\subsection{Water Ingress Restrictions}

During construction, thresholds across the tunnel floor were made to measure the water ingress, and water ingress restrictions (threshold values) were defined as shown in Table 2.

Regarding the potential settlement of buildings, the depression between profile nos. 1300 and 1150 was the main concern during planning and excavation. Based on settlement calculations and empirical data of water ingress and pore pressure reduction in the Oslo region, a relationship was established between water ingress and settlement at profile no. 1250 (Henriksen and Føyn 2004), as shown in Table 3. This relationship was used during construction when deciding whether a planned watertight concrete lining between profile nos. 1220 and 1300 should be built or not.

An extensive monitoring programme was established to survey the potential settlement of buildings above the tunnel.

\subsection{Grouting}

Due to the very strict water ingress restrictions, maximum 7-10 1/min/100 $\mathrm{m}$ for both tubes combined, systematic
Table 2 Water ingress restrictions

\begin{tabular}{lll}
\hline From & To & $\begin{array}{l}\text { Leakage for both tubes } \\
\text { combined }(1 / \mathrm{min} / 100 \mathrm{~m})\end{array}$ \\
\hline 640 & 800 & $<10$ \\
800 & 1350 & $<7$ \\
1350 & 1500 & $<10$ \\
1500 & 1560 & $<7$ \\
\hline
\end{tabular}

Table 3 Relationship between pore pressure reduction, settlement and water ingress restrictions at profile no. 1250 (Henriksen and Føyn 2004)

\begin{tabular}{lcl}
\hline $\begin{array}{l}\text { Pore pressure } \\
\text { reduction }(\mathrm{m})\end{array}$ & $\begin{array}{l}\text { Settlement } \\
(\mathrm{cm})\end{array}$ & $\begin{array}{l}\text { Water ingress for both tubes } \\
\text { combined }(1 / \mathrm{min} / 100 \mathrm{~m})\end{array}$ \\
\hline 1 & 3 & 3 \\
3 & 8 & 7 \\
5 & 12 & 10 \\
10 & 20 & 20 \\
\hline
\end{tabular}

pre-excavation grouting was planned and carried out for the entire tunnel.

\subsubsection{Grout Rig}

The grouting rig was equipped with three separate pumping lines and a storage cement mixer for each line. The cement was first mixed in the main cement mixer and then pumped into the storage mixers. There was also a tank and a pump for the accelerator to ensure controlled curing. The rig was operated by an electronic panel with predefined cement recipes.

\subsubsection{Grout Curtains ${ }^{1}$}

Grout curtains with 45-46 holes circumferencing the face and 7-9 holes in the face itself, as shown in Fig. 8, have been used. The hole length was 15, 21 or $23 \mathrm{~m}$, depending on the distance between the curtains and the blast length, and the curtain overlap was 7-9 $\mathrm{m}$. Spacings between the holes were $1.0 \mathrm{~m}$ at the floor and $0.8 \mathrm{~m}$ in the walls and crown.

After completing the drilling of a curtain, grouting rods were placed in the holes with the tap open. For large leakages, the rods were placed in the holes during drilling with the tap closed. The grouting rods were $3 \mathrm{~m}$ long and had a disposable packer with a mechanical expansion sleeve at the end. The packer reflux valve was left open before grouting to let water pass, by inserting a nail in the cross opening.

${ }^{1}$ In this article, also the word 'section' is used as a term for one grouting round, which consists of one grout curtain. The profile number relating to this is from where the grout curtain is drilled. 


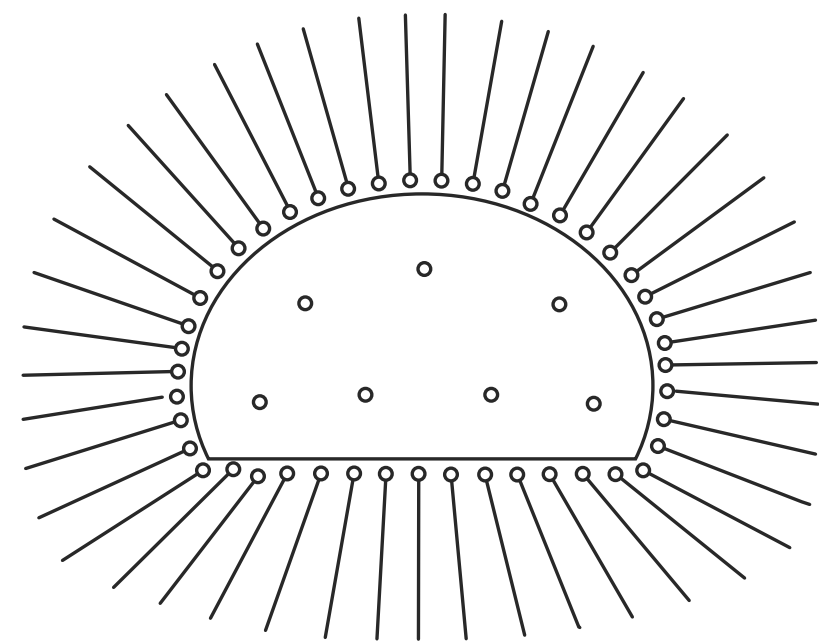

Fig. 8 Typical drill plan for grout curtains

Table 4 Sections with different cement types

\begin{tabular}{lll}
\hline From & To & Cement type \\
\hline B1550 & B1301 & Rapid cement \\
B1294 & B1165 & Micro-cement \\
B1159 & B1022 & $\begin{array}{l}\text { Rapid cement, used some micro-cement in extra } \\
\text { curtain at B1022 }\end{array}$ \\
B1011 & B0936 & Micro-cement \\
B924 & B762 & Rapid cement \\
B757 & B667 & $\begin{array}{l}\text { Micro-cement } \\
\text { B745 }\end{array}$ \\
B1186 & & $\begin{array}{l}\text { Single section with rapid cement } \\
\text { Single section with rapid cement }\end{array}$ \\
\hline
\end{tabular}

\subsubsection{Grouting Procedure}

Cement has been used for all systematic grouting, normally with a w/c ratio span of 1.0 to 0.5 , see Table 4 . The grouting sequence started with two lines in the middle of the bottom holes. The lines were then moved from this position to both sides, and further up the walls, until they met at the crown. The third line was either used in the face holes or together with one of the other lines to grout two holes next to each other (see Fig. 9). The choice of grout cement type was mainly based on overburden evaluation and ingress restrictions. Rapid cement has the lowest cost and was, therefore, the preferred choice. Micro-cement is believed to have a better penetration than rapid cement (Axelsson et al. 2009) and was used when the overburden was low and high pressures might cause the grout to reach the surface and in cases when rapid cement did not give a satisfactorily tight tunnel. The cement was defined as rapid cement when it had a grain size $d_{95}>20 \mu \mathrm{m}$ and micro-cement when it had a grain size $d_{95}<20 \mu \mathrm{m}$.

The stop criterion for grouting was when the pressure in the hole reached a certain value (the end pressure) and zero

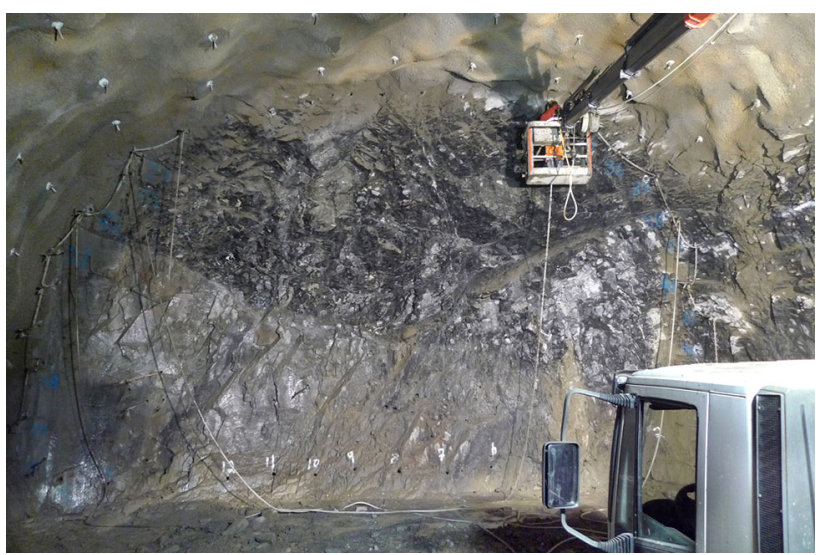

Fig. 9 Grouting in progress

grout flow. In areas with small rock cover, the stop criterion (end pressure) was divided into bottom and top, where the top holes were defined as those above the invert (see Table 5).

When grouting, it is generally important to have some grout consumption and pressure build-up in the hole in order to make a tight tunnel (Brantberger et al. 2000). Therefore, grouting at the Løren tunnel, as shown in Table 5, was started with a highly liquid grout, which was made less liquid by lowering the w/c ratio (for rapid cement) or adding curing liquid (for micro-cement) to build up pressure during the grouting process for the hole. If there was no sign of pressure build-up after this, the hole was set on hold (e.g. for an hour) before grouting was resumed.

For the controlled curing, the accelerator was mixed with the grout at the rod. The contractually described controlled curing for rapid cement (see Table 5) did not work due to the chemical composition of the cement.

During construction, it was detected that the pumping system for the accelerator was not operating as it was supposed to. It was found that the pump fed a lower amount than the percentage shown on the panel. Towards the end of the construction time (around profile no. B757), this was taken into account by using a higher setting than that described.

\section{MWD and DPI}

\subsection{Background and Basic Principles}

Measurement while drilling (MWD has a history from the early 1900s when Schlumberger introduced downhole electrical logging to the oil industry (Segui and Higgins 2002; Smith 2002). When the mining industry started to adapt the method, the logged data were plotted on paper 
Table 5 Grouting procedures for respective sections of the Løren tunnel

\begin{tabular}{|c|c|c|c|c|}
\hline Date & $\begin{array}{l}\text { Profile } \\
\text { number }\end{array}$ & $\begin{array}{l}\text { Hole } \\
\text { length }(m)\end{array}$ & $\begin{array}{l}\text { End pressure } \\
\text { (bottom/top) (bar) }\end{array}$ & $\begin{array}{l}\text { Description of the grouting procedure } \\
\text { for a hole in the curtain }\end{array}$ \\
\hline 2009.06 .23 & В1550-B1535 & 23 & 45 & $\begin{array}{l}\text { Rapid cement } \\
3401 \mathrm{w} / \mathrm{c} 1.0 \\
3451 \mathrm{w} / \mathrm{c} 0.8 \\
3301 \mathrm{w} / \mathrm{c} 0.7 \\
6001 \mathrm{w} / \mathrm{c} 0.5 \\
\text { At volumes }<1001 \text {, hold pressure at } 80 \text { bar for } 5 \mathrm{~min} \\
\text { At volumes }>1,5001 \text {, the end pressure is } 30 \text { bar }\end{array}$ \\
\hline 2009.08 .07 & B1525 & 15 & 80 & Same as above \\
\hline 2009.08 .07 & B1520-B1452 & 23 & 80 & Same as above \\
\hline 2009.09 .17 & B1440-B1385 & 23 & 80 & $\begin{array}{l}\text { Rapid cement } \\
3401 \mathrm{w} / \mathrm{c} 1.0 \\
3301 \mathrm{w} / \mathrm{c} 0.7 \\
1,2001 \mathrm{w} / \mathrm{c} 0.5 \\
\text { At volumes }>1,8701 \text {, controlled curing to stop grouting } \\
\text { At volumes }<1001 \text {, hold pressure at } 80 \text { bar for } 5 \mathrm{~min} \\
\text { At volumes }>1,5001 \text {, the end pressure is } 30 \mathrm{bar}\end{array}$ \\
\hline 2009.10 .22 & B1379-B1346 & 18 & 80 & Same as above \\
\hline 2009.11.15 & B1333-B1301 & 18 & 80 & $\begin{array}{l}\text { Rapid cement } \\
3401 \mathrm{w} / \mathrm{c} 1.0 \\
3301 \mathrm{w} / \mathrm{c} 0.7 \\
1,2001 \mathrm{w} / \mathrm{c} 0.5 \\
\text { At volumes }>1,8701 \text {, controlled curing to stop grouting }\end{array}$ \\
\hline 2009.12 .08 & B1294-B1274 & 19 & $80 / 60$ & $\begin{array}{l}\text { Micro-cement } \\
3401 \mathrm{w} / \mathrm{c} 1.0 \\
3401 \mathrm{w} / \mathrm{c} 0.8 \\
8001 \mathrm{w} / \mathrm{c} 0.5 \\
\text { At volumes }>1,5001 \text {, controlled curing if pressure }<30 \mathrm{bar}\end{array}$ \\
\hline 2010.01 .18 & B1265 & 19 & $60 / 40$ & $\begin{array}{l}\text { Micro-cement } \\
1,0001 \mathrm{w} / \mathrm{c} 0.8 \\
\text { Controlled curing }(2 \%) \text { at } 8001 / \text { hole } \\
\text { Controlled curing }(5 \%) \text { at } 1,0001 \text { to stop grouting } \\
\text { Max. } 9 \mathrm{~m} \text { between grouting curtains }\end{array}$ \\
\hline 2010.02 .02 & B1258-B1239 & 15 & & $\begin{array}{l}\text { Same as above } \\
\text { Max. } 6 \mathrm{~m} \text { between grouting curtains }\end{array}$ \\
\hline 2010.02 .22 & B1230-B1178 & 15 & $60 / 40$ & $\begin{array}{l}\text { Same as above } \\
\text { Max. } 8 \mathrm{~m} \text { between grouting curtains }\end{array}$ \\
\hline 2010.04.08 & B1174-B1165 & 15 & $60 / 40$ & $\begin{array}{l}\text { Same as above } \\
\text { Max. } 4 \mathrm{~m} \text { between grouting curtains }\end{array}$ \\
\hline 2010.04 .23 & B1161-B1154 & 15 & $80 / 80$ & $\begin{array}{l}\text { Rapid cement } \\
3401 \mathrm{w} / \mathrm{c} 1.0 \\
3301 \mathrm{w} / \mathrm{c} 0.7 \\
5301 \mathrm{w} / \mathrm{c} 0.5 \\
3001 \mathrm{w} / \mathrm{c} 0.5 \text { with controlled curing } \\
\text { At volumes }<1001 \text {, hold pressure at } 80 \text { bar for } 5 \mathrm{~min} \\
\text { At volumes }>1,5001 \text {, the end pressure is } 30 \text { bar } \\
\text { Max. } 9 \text { m between grout curtains }\end{array}$ \\
\hline
\end{tabular}


Table 5 continued

\begin{tabular}{|c|c|c|c|c|}
\hline Date & $\begin{array}{l}\text { Profile } \\
\text { number }\end{array}$ & $\begin{array}{l}\text { Hole } \\
\text { length (m) }\end{array}$ & $\begin{array}{l}\text { End pressure } \\
\text { (bottom/top) (bar) }\end{array}$ & $\begin{array}{l}\text { Description of the grouting procedure } \\
\text { for a hole in the curtain }\end{array}$ \\
\hline 2010.05 .04 & B1144-B1085 & 21 & $80 / 80$ & $\begin{array}{l}\text { Rapid cement } \\
3401 \mathrm{w} / \mathrm{c} 1.0 \\
3301 \mathrm{w} / \mathrm{c} 0.7 \\
2301 \mathrm{w} / \mathrm{c} 0.5 \\
2001 \mathrm{w} / \mathrm{c} 0.5 \text {, controlled curing if pressure is }<30 \mathrm{bar} \\
\text { At volumes }<1001 \text {, hold pressure at } 80 \text { bar for } 5 \mathrm{~min} \\
\text { Max. } 10 \mathrm{~m} \text { between grouting fans }\end{array}$ \\
\hline 2010.05 .20 & B1074-B1122 & 23 & $80 / 80$ & $\begin{array}{l}\text { Same as above } \\
\text { Max. } 12 \mathrm{~m} \text { between grout curtains }\end{array}$ \\
\hline 2010.08 .11 & B1011-B935 & 23 & $60 / 40$ & $\begin{array}{l}\text { Micro-cement } \\
8001 \mathrm{w} / \mathrm{c} 0.8 \\
2001 \mathrm{w} / \mathrm{c} 0.8 \text {, controlled curing } 2 \% \\
\text { At volumes }>1,0001 \text {, controlled curing } 5 \% \\
\text { Max. } 12 \mathrm{~m} \text { between grouting curtains }\end{array}$ \\
\hline 2010.09 .21 & B924 - B 901 & 23 & $60 / 40$ & $\begin{array}{l}\text { Rapid cement } \\
7001 \mathrm{w} / \mathrm{c} 0.7 \\
5001 \mathrm{w} / \mathrm{c} 0.5 \\
\text { At volumes }>1,200 \text {, grouting is ended } \\
\text { Max. } 12 \mathrm{~m} \text { between grouting curtains }\end{array}$ \\
\hline 2010.10 .06 & B892-B762 & 23 & $60 / 60$ & $\begin{array}{l}\text { Rapid cement } \\
3001 \mathrm{w} / \mathrm{c} 1.0 \\
3001 \mathrm{w} / \mathrm{c} 0.7 \\
4001 \mathrm{w} / \mathrm{c} 0.5 \\
\text { After } 9001 \text { and pressure }<30 \mathrm{bar} \text {, a break in grouting is taken } \\
\text { Max. } 12 \mathrm{~m} \text { between grouting curtains }\end{array}$ \\
\hline 2010.12.03 & B $757^{\mathrm{b}}-\mathrm{B} 735$ & 23 & $60 / 60$ & $\begin{array}{l}\text { Micro-cement } \\
3001 \mathrm{w} / \mathrm{c} 0.8 \\
3001 \mathrm{w} / \mathrm{c} 0.5 \\
1501 \mathrm{w} / \mathrm{c} 0.5 \text {, controlled curing } 3 \% \\
1501 \mathrm{w} / \mathrm{c} 0.5 \text {, controlled curing } 6-8 \% \\
\text { Max. } 12 \mathrm{~m} \text { between grouting curtains }{ }^{\mathrm{c}}\end{array}$ \\
\hline 2011.01.03 & B723-B767 & 23 & $60 / 40$ & Same as above \\
\hline
\end{tabular}

${ }^{a}$ The grouting procedure used from B924 was changed because the grout volumes were too low to obtain a tight tunnel

b There was grouting twice at B762, first with rapid cement and then micro-cement, because of an initially poor grouting result. Only the rapid cement grouting curtain is included in the dataset

c On some occasions, the distance is $6 \mathrm{~m}$

with pen strip recorders and the drill parameters were inspected manually. When computers were introduced, new possibilities with filtering and advanced statistical analysis became available (Schunnesson 1997) for proper drill parameter interpretation (DPI). The latest software on the market uses 3D technology to present the data and, together with easy-to-use interfaces, the method is now a good tool to predict the rock conditions for mining and tunnelling purposes.

During drilling, the parameters from the machine control are logged and saved in files. These data are stored together with the hole position, hole direction, drill hammer ID and other relevant data. An example of the logged parameters is shown in Table 6.

In tunnelling and mining, the DPI usually gives three factors that describe the rock condition: rock hardness, fracturing and water. The levels of these three factors can be combined to describe other types of rock properties, e.g. drillability and blastability, and it can be evaluated, for instance, when to start spiling and rock mass grouting.

In the case of mining for example, the hardness factor can be used to find the boundary between the ore body and 
Table 6 Example of logged parameters from a log file

\begin{tabular}{|c|c|c|c|c|c|c|c|c|c|}
\hline $\mathrm{HD}(\mathrm{mm})^{\mathrm{a}}$ & $\mathrm{PR}(\mathrm{dm} / \mathrm{min})^{\mathrm{b}}$ & HP $(\text { bar })^{\mathrm{c}}$ & $\mathrm{FP}(\text { bar })^{\mathrm{d}}$ & $\mathrm{DP}(\text { bar })^{\mathrm{e}}$ & $\operatorname{RS}(\mathrm{r} / \mathrm{min})^{\mathrm{f}}$ & $\mathrm{RP}(\text { bar })^{\mathrm{g}}$ & $\mathrm{WF}(1 / \mathrm{min})^{\mathrm{h}}$ & WP (bar) ${ }^{\mathrm{i}}$ & Time \\
\hline 32 & 0 & 69.76 & 19.69 & 39.65 & 216.86 & 42.47 & 76.09 & 21.4 & $8: 18: 49$ \\
\hline 59 & 31.83 & 101.44 & 17.12 & 40.08 & 217.77 & 38.61 & 76.84 & 20.97 & $8: 18: 49$ \\
\hline 84 & 30.28 & 111.71 & 17.12 & 40.08 & 218.68 & 39.47 & 75.72 & 20.97 & $8: 18: 50$ \\
\hline 108 & 28.37 & 116.42 & 19.26 & 40.51 & 219.60 & 42.04 & 75.72 & 21.83 & $8: 18: 50$ \\
\hline 131 & 26.75 & 123.26 & 20.97 & 40.51 & 214.11 & 53.20 & 76.46 & 20.97 & $8: 18: 51$ \\
\hline 152 & 24.88 & 124.98 & 24.82 & 40.51 & 198.56 & 51.48 & 76.46 & 22.26 & $8: 18: 52$ \\
\hline$\ldots$ & $\ldots$ & $\ldots$ & $\cdots$ & $\cdots$ & $\cdots$ & $\cdots$ & $\cdots$ & $\cdots$ & $\cdots$ \\
\hline
\end{tabular}

\footnotetext{
${ }^{a}$ Hole depth

b Percussion rate

c Hammer pressure

${ }^{\mathrm{d}}$ Feeding pressure

e Dampening pressure

${ }^{\mathrm{f}}$ Rotation speed

g Rotation pressure

h Water flow

${ }^{\mathrm{i}}$ Water pressure
}

the side rock. In tunnelling, a common use of DPI is to evaluate the quality of the rock mass in exploratory boreholes in order to adjust the support level when advancing towards weakness zones.

The water and fracturing factors are not yet very commonly used, but one example is Norra Länken in Stockholm, where the interpreted parameters were evaluated while drilling the grout curtain. When starting on a new curtain, every second of the holes were drilled first and the drill logs sent to the site office. An engineering geologist evaluated the interpreted data and ordered extra holes if required according to the DPI grouting class (Carlsvärd and Wallgren 2009).

The DPI software that has been used at the Løren tunnel is GPM+ Tunnel, delivered by Rockma AB (2011). $\mathrm{GPM}+$ calculates three factors: hardness, fracturing and water. The values are on a relative scale, but the hardness factor can be adjusted based on rock strength tests (e.g. Schmidt hammer or point load) to estimate the uniaxial strength (Valli 2010).

GPM+ uses different statistical methods and filtering for the calibration and processing of data. The calibration must be done at each work site and for each drill rig in order to obtain a satisfactory result. The calibration is done based on a principal component analysis to discover which of the parameters are relevant, and to what degree they are relevant. The algorithms are based on the work of Schunnesson (1997).

For calculating the DPI factors, GPM+ uses the values from the parameters in the log file (see Table 6) for each sample, and returns a value for each of the DPI factors (hardness, fracture and water) for each sample point. The

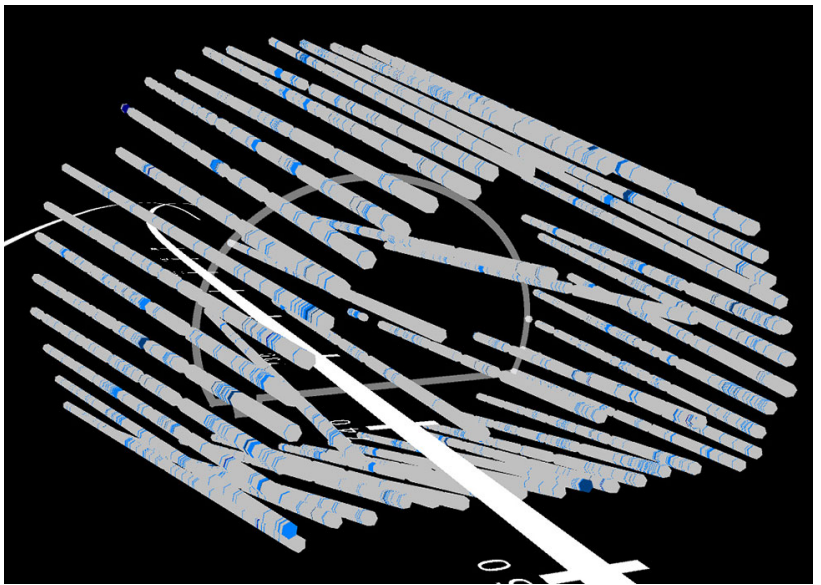

Fig. 10 Screenshot from GPM + showing the water factor for a grouting section in $3 \mathrm{D}$

hardness is, in this case, calibrated to show the uniaxial strength. The fracturing factor indicates that the rock is fractured and the water factor indicates that water is flowing from the rock. A higher value indicates a higher degree of fractures or more water. In GPM+, the water factor is set to show water for values higher than 1.5 and to show fracturing for fracturing values higher than 1.0. See Figs. 10 and 11.

\subsection{Data Collection}

\subsubsection{Water Ingress Measurement}

As mentioned in Sect. 2.2, thresholds across the tunnel floor were made to measure the water ingress during construction. The construction road runs over the thresholds, 


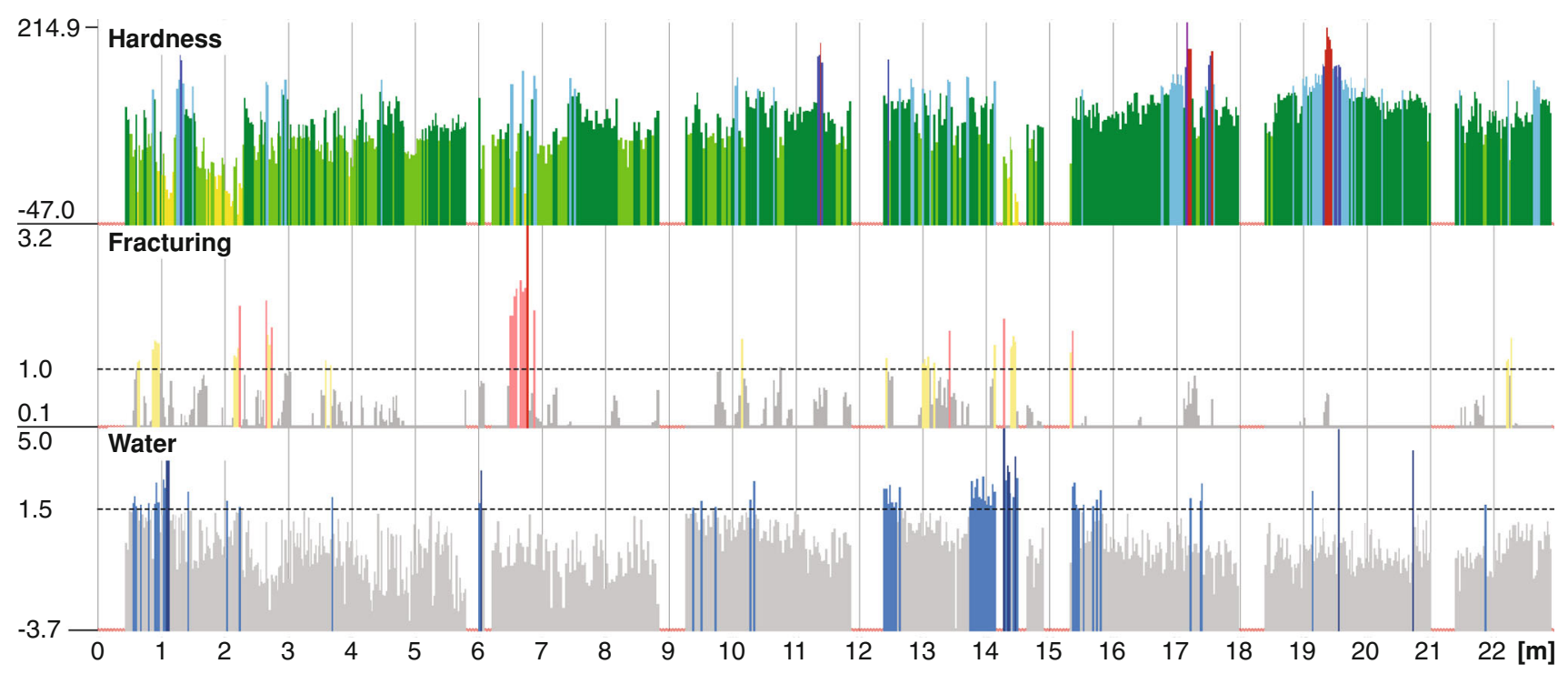

Fig. 11 Screenshot from GPM+ showing (from the top) hardness, fracturing and water along one borehole

with a ditch on the side for the water to flow and stop behind the threshold. The water was lead through the threshold with a pipe and the water volume was measured by collecting the water in buckets for $1 \mathrm{~min}$. The water volume from the upstream threshold was subtracted and the spacing between them taken into account by dividing the distance and multiplying by $100(\mathrm{~m})$ to obtain $\mathrm{l} / \mathrm{min} / 100 \mathrm{~m}$.

The main concern by using this method is that blasting and crushing by large vehicles creates mud and silt that fills up behind the thresholds and clogs the drainage in the top layer of the construction road. The space behind the thresholds, therefore, have to be maintained regularly by removing the silt and clay. To lead all the water into the ditch and, at the same time, having the construction road driveable for vehicles is challenging, and water may easily follow the construction road and pass over the thresholds. Also, other uses of the tunnel space during construction, e.g. storing and temporary installations, may conflict with leading the water into the thresholds. In addition, an area at the low point lacks water ingress measurement because of the cross-cut and space for water sedimentation.

\subsubsection{Leakage Mapping and Comparison with the DPI Water Factor}

After the excavation of the tunnel was completed, a manual mapping of leakages from the tunnel roof and walls was performed. The mapping covered point as well as area leakages. The volume of leakages is measured in drops $/ \mathrm{min}$ or $1 / \mathrm{min}$. The registration is done on a fold-out tunnel profile and is registered in Novapoint Tunnel.

In GPM+, there is an export function where the DPI factors are interpolated and saved to a fold-out tunnel profile. These files were imported to Novapoint Tunnel and can be viewed together with the water leakage information. Small impacts of the water factor may be erased during the interpolation process.

\subsection{Processing of DPI and Grouting Data}

To investigate the relationship between DPI and grouting data, some processing of the DPI data and matching of DPI and grouting data had to be done. The dataset consists of data from two sources: interpreted drill data done by GPM+ Tunnel and grout logs from the grouting rig. The statistical software program SPSS (IBM 2010) was used to pair up these datasets and recalculate DPI values. The program has also been used for descriptive purposes and chart building.

\subsubsection{Interpreted Drill Data}

GPM+ mainly shows the interpreted data graphically, with colour scales representing different values. For the purpose of statistical analyses and charts, number values are needed, and Rockma Systems AB, therefore, exported all measuring points (one point every $2-3 \mathrm{~cm}$ in all holes) into text files. These text files were imported into SPSS and resulted in a dataset with over 2 million measuring points.

To compare the interpreted data with the grouting data, one value for each factor (water and fracturing) for each hole is needed. Based on the experience of Rockma Systems $\mathrm{AB}$, values for water higher than 1.5 indicate waterbearing fractures and fracturing values higher than 1.0 indicate fractured rock. To provide one value for each hole, a filtering and recalculation for each factor was performed. 
For the water factor, all sample values $\leq 1.5$ were filtered out. Sample values $\geq 1.5$ were subtracted 1.5 and multiplied with their sample length and then added:

$W=\sum_{i=m}^{n}(((w \geq 1.5)-1.5) * l)_{i}$

where $W$ is the water value for a hole, $n$ the number of samples for a hole, $w$ a single water value and $l$ is the sample length.

For the fracturing factor, all sample values $\leq 1.0$ were filtered out. Sample values $\geq 1.0$ were subtracted 1.0 and multiplied with their sample length and then added:

$F=\sum_{i=m}^{n}(((f \geq 1.0)-1.0) * l)_{i}$

where $F$ is the fracturing value for a hole, $n$ the number of samples for a hole, $f$ a single fracturing value and $l$ is the sample length.

$W$ and $F$ factors were then added in a new dataset, along with their section numbers, hole numbers and hole lengths. This dataset contained 3,611 cases (holes).

When water and fracturing values are presented for a section, the $W$ and $F$ factors are added for that section. In the results for the water factor, it is a trend that the impact is larger with decreasing profile number. A linear trend line was calculated and the difference quotient for this line has been used to normalise the data by recalculating the values to have a horizontal trend line, to make them comparative through the tunnel.

\subsubsection{Grouting Data}

The grouting data were obtained based on the log files from the grouting rig and saved as spreadsheets containing the weight of cement used and the amount of grout in litres for each recipe and hole. The values for each hole were added, giving the weight of cement and litres of grout for each hole. The weight of cement was divided into three categories: rapid cement, micro-cement and micro-cement with controlled curing.

\subsubsection{Hole Number Matching}

The hole numbers from grouting data and drill data were not corresponding. The hole numbering for the grouting data started at the lower right corner and proceeded clockwise around the contour, with the face holes as the last numbers. The hole numbering for the drill data was more or less random, but could be viewed together with the drill pattern in GPM+.

The hole numbers, therefore, were punched manually to make the two data sources correspond. For the start of the tunnel, it was hard to decide where to start the hole numbering, and this part is, therefore, excluded from the dataset, as well as a couple of sections where there was doubt about where the hole numbering started. All face holes are also excluded from the dataset due to difficulties with the hole numbers matching.

\subsubsection{Content of the Dataset}

The dataset spans over profile nos. B1224 to B641 and has 59 different sections/grouting rounds and 2,606 cases/ holes. This data was picked out because tube B was excavated approximately $30 \mathrm{~m}$ ahead of tube A and the grouting, therefore, is done without any disturbance from the other face. Hole number matching was difficult between B1560 and B1224, and this section was, therefore, excluded.

The main variables in the dataset are:

- Section number

- Hole number

- Hole length

- Hole number from drill data

- Hole number from grouting data

- Rapid cement weight

- Micro-cement weight

- Micro-cement with controlled curing weight

- Grout volume

- $W$ : water factor for a hole

- $F$ : fracturing factor for a hole

\section{Results From the Tunnelling}

The presentation of the results is divided into two main parts, grouting and DPI. The grouting part has its main focus on describing water ingress and on how the challenging grouting past the rock depression between profile nos. 1300 and 1150 was handled. Some findings regarding grout consumption in holes are also presented. The DPI part focuses on a comparison between the grouting volumes and DPI factors for selected sections.

\subsection{Grouting}

\subsubsection{Water Ingress}

As shown in Table 7, the water ingress values are generally below the restriction (threshold) values for one tube, and sometimes slightly exceed the restrictions when the values for the two tubes are added.

The sampled distances do not match the ingress restrictions because the placing of the thresholds had to be 
Table 7 Water ingress for tubes A and B measured 03.01.2011

\begin{tabular}{llll}
\hline From & To & $1 / \mathrm{m}$ & $1 / \mathrm{m} / 100 \mathrm{~m}$ \\
\hline A1545 & A1355 & $6.0^{\mathrm{a}}$ & $3.2^{\mathrm{a}}$ \\
A1300 & A1220 & 2.7 & 3.4 \\
A1220 & A1050 & 8.0 & 4.7 \\
A1050 & A749 & 4.0 & 1.3 \\
B1562 & B1385 & $12.0^{\mathrm{b}}$ & $6.8^{\mathrm{b}}$ \\
B1303 & B1232 & 3.0 & 4.2 \\
B1232 & B1060 & 5 & 2.9 \\
B1060 & B723 & $7.6^{\mathrm{c}}$ & $2.3^{\mathrm{c}}$ \\
\hline
\end{tabular}

${ }^{a}$ Measured 05.04.2012

b Measured 03.01.2012

c Measured 02.01.2011. There are some uncertainties regarding this measurement

adjusted to the placing of low points, cross-cuts etc. Because of this, some assessment of the values had to be made when considering whether the restrictions are met or not.

The $7 \mathrm{l} / \mathrm{min} / 100 \mathrm{~m}$ restriction for profile nos. 1560-1500 is a part of a bigger sample interval, but when looking at the leakage mapping, there are not many leakages in this area and, therefore, it is probably below the restriction value. The same assumption applies for profile nos. 800-640, where a part of this interval is not a part of a sample.

\subsubsection{Passing the Rock Depression, Profile nos. $1300-1150$}

The biggest challenge during the construction of the Løren tunnel was passing the rock depression between profile nos. 1300-1150. As mentioned before, the rock overburden was 6-8 $\mathrm{m}$ and the soil thickness was $30 \mathrm{~m}$ for a $50-\mathrm{m}$ section in this area. The excavation through this section was done with 3-m blast rounds, and spiling, shotcrete, rock bolts and rebar-reinforced shotcrete ribs as rock support. Exploratory boreholes from the tunnel face were drilled to make sure that the overburden was as expected.

Because of the potential consequences for buildings at the surface if the water ingress was too high after rock mass grouting, it was prepared for a watertight concrete lining between profile nos. 1300-1220. During excavation, a larger profile with an arched floor was blasted to make room for this construction.

Due to problems during rock mass grouting around the building pit, the water level in the depression was lowered 5-6 $\mathrm{m}$ before tunnel excavation started. This lowering was expected to be temporary because barriers and watertight constructions would allow the water level to rise in the building pit when excavation was finished.
To raise the groundwater level and reduce the settlement, infiltration from the surface was started prior to tunnel excavation. In addition, infiltration from the two infiltration boreholes in the tunnel tubes was started when the excavation had passed the depression.

To decide whether the watertight lining should be built or not, a thorough evaluation of water ingress, groundwater level and ground reaction due to the lowering of the groundwater had to be made. To get a better understanding on how the infiltration affected the groundwater level, the infiltration was stopped for two periods. The curves from the observation wells were flattening out after approximately 14 days and showed a lowering of the groundwater level by approximately $2 \mathrm{~m}$ (Boge 2010).

The calculated settling was $50-100 \mathrm{~mm}$, and without water infiltration, an additional $50 \mathrm{~mm}$. The registered settlements of buildings were smaller than expected and it is reason to believe that soil is more pre-consolidated than the laboratory testing shows. Levelling measurements on a building founded on rock showed a $30-\mathrm{mm}$ lifting, which is assumed to be a result from hydraulic splitting of the rock from the rock mass grouting (Boge 2010). Measurements done on buildings on other parts of the tunnel also indicate this.

When deciding whether the watertight lining should be built or not, a conservative assumption was made of further settling of 70-100 mm if the water infiltration was turned off. This was believed to represent minor harm for buildings. It was also concluded that the building of the watertight lining would have a minor influence on the groundwater level (Boge 2010). It was, therefore, decided not to build the lining and to turn off the water infiltration (Barstad 2010).

The grouting in the rock depression area resulted in water ingress corresponding to the requirements in the contract. After the groundwater level in the building pit was re-established, the groundwater level in the area is nearly the same as before the project started. Settlements of the most exposed buildings are in the order of magnitude of $30-40 \mathrm{~mm}$. The settlement seems to have stopped and there has been little damage to buildings due to groundwater lowering (Boge 2012).

\subsubsection{Grout Consumption}

The grout volume frequencies for all holes are shown in Fig. 12. The histogram illustrates that a large amount of holes had a grout consumption less than 1001 . For most of the grouting procedures in the dataset, the maximum grout volume for a hole was 1,000 1. For holes with a consumption of more than about 1,000 1, the end pressure was hard to achieve. Holes with a grout consumption above 


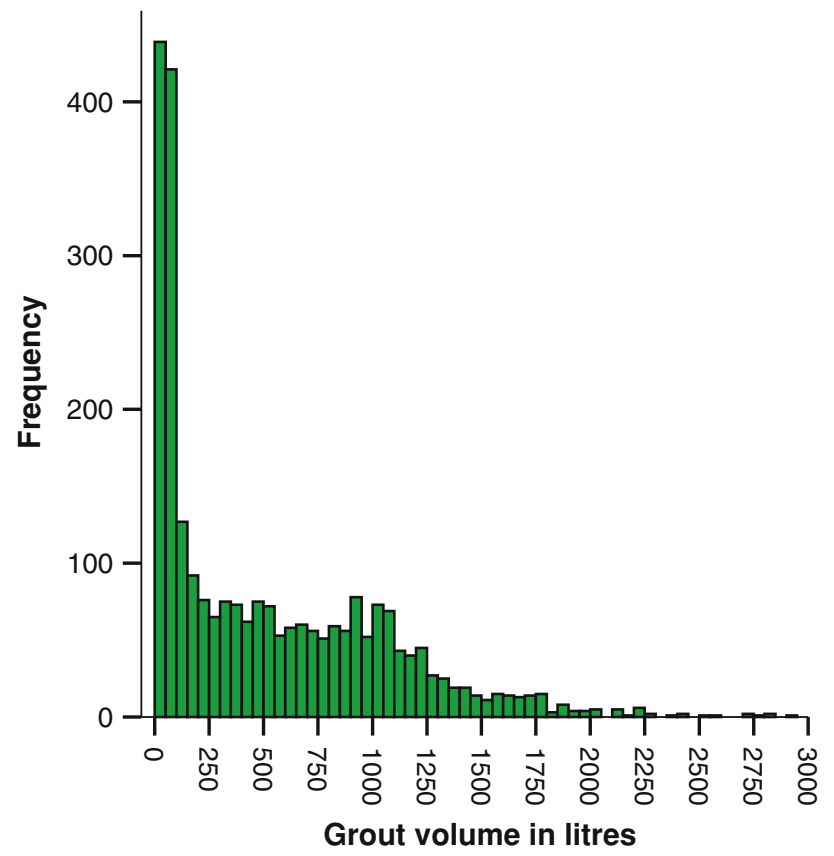

Fig. 12 Grout volume frequencies for all holes, $N=2,606$

$1,250-1,500$ may be a result of flow back into the tunnel through fractures.

In Fig. 13, a detailed frequency diagram is shown for holes with $23 \mathrm{~m}$ length grouted with rapid cement. The theoretical volume of these holes is $471_{1}^{2}$ but the volume might be larger because the actual hole diameter might have been wider and because fall-out of small rock pieces might have occurred. In addition, pressure buildup in the hoses and filling of the rods uses some grout. The peak around 521 is, therefore, an indication that a large part of the holes only is filled with grout, with no penetration into the rock mass.

As shown in Fig. 14, holes grouted with micro-cement does not have a peak at around 551 , as in the holes grouted with rapid cement. A large amount of holes with almost no grout consumption can be observed in this figure, in contrast to what can be observed for the rapid cement holes in Fig. 13.

\subsection{Drill Parameter Interpretation}

\subsubsection{Water Leakage}

The mapped water leakage has a generally good match with the DPI water factor, although the mapping is done after the grouting was finished. This match indicates that, when the water factor shows water, water is quite likely actually present in the hole. Since the water may find new channels during grouting and positioning while mapping is

\footnotetext{
${ }^{2}$ Drill bit diameter $54 \mathrm{~mm}, 23 \mathrm{~m}$ hole length minus $2.5 \mathrm{~m}$ for packer placement.
}

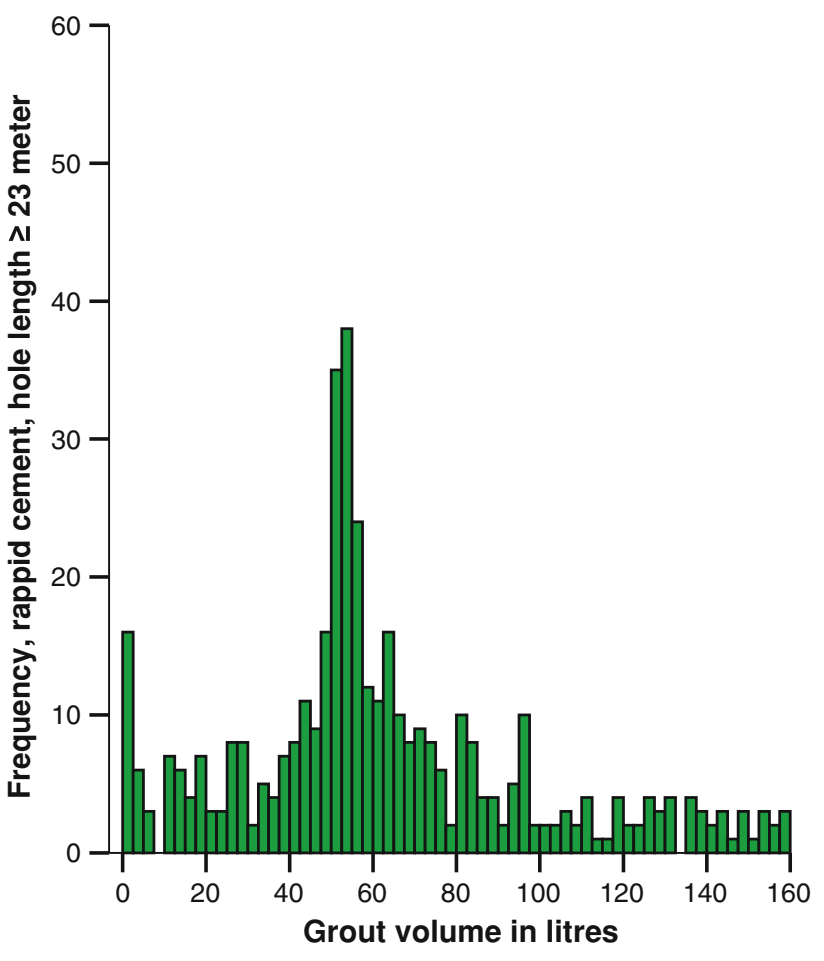

Fig. 13 Grout volume frequencies of holes filled with rapid cement and hole length $\geq 23 \mathrm{~m}$ (grout volume is cut at 1601 ), $N=986$

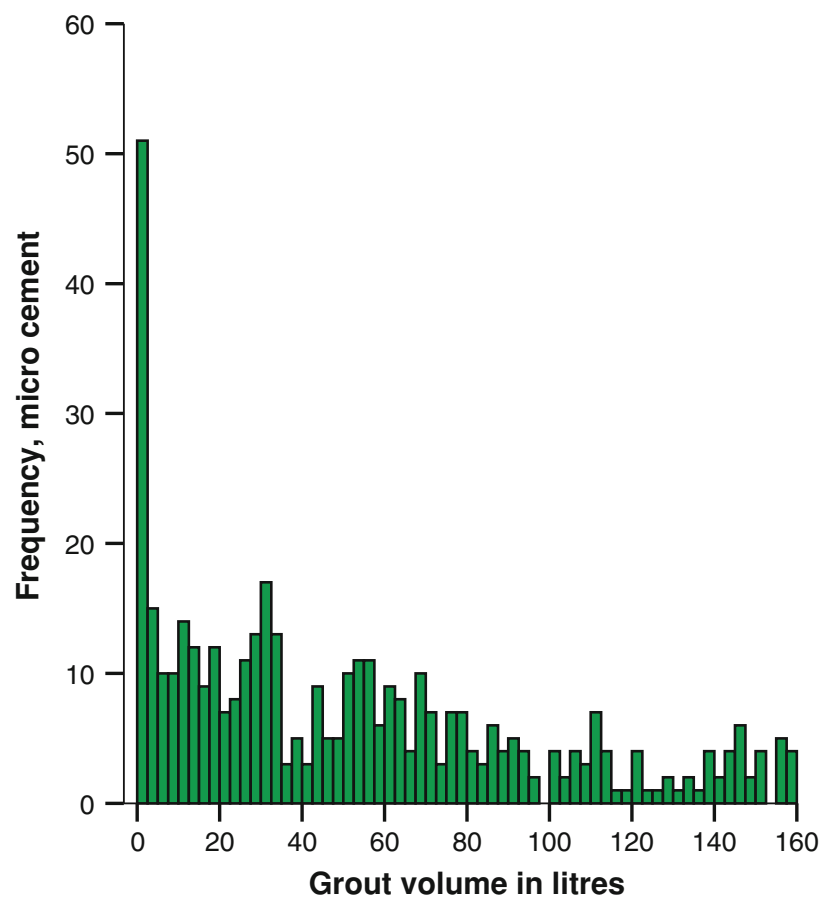

Fig. 14 Grout volume frequencies of holes grouted with microcement (grout volume is cut at 1601 ), $N=1,098$

challenging, an exact match cannot be expected. An example of mapped leakage versus water factor from DPI is shown in Fig. 15. 

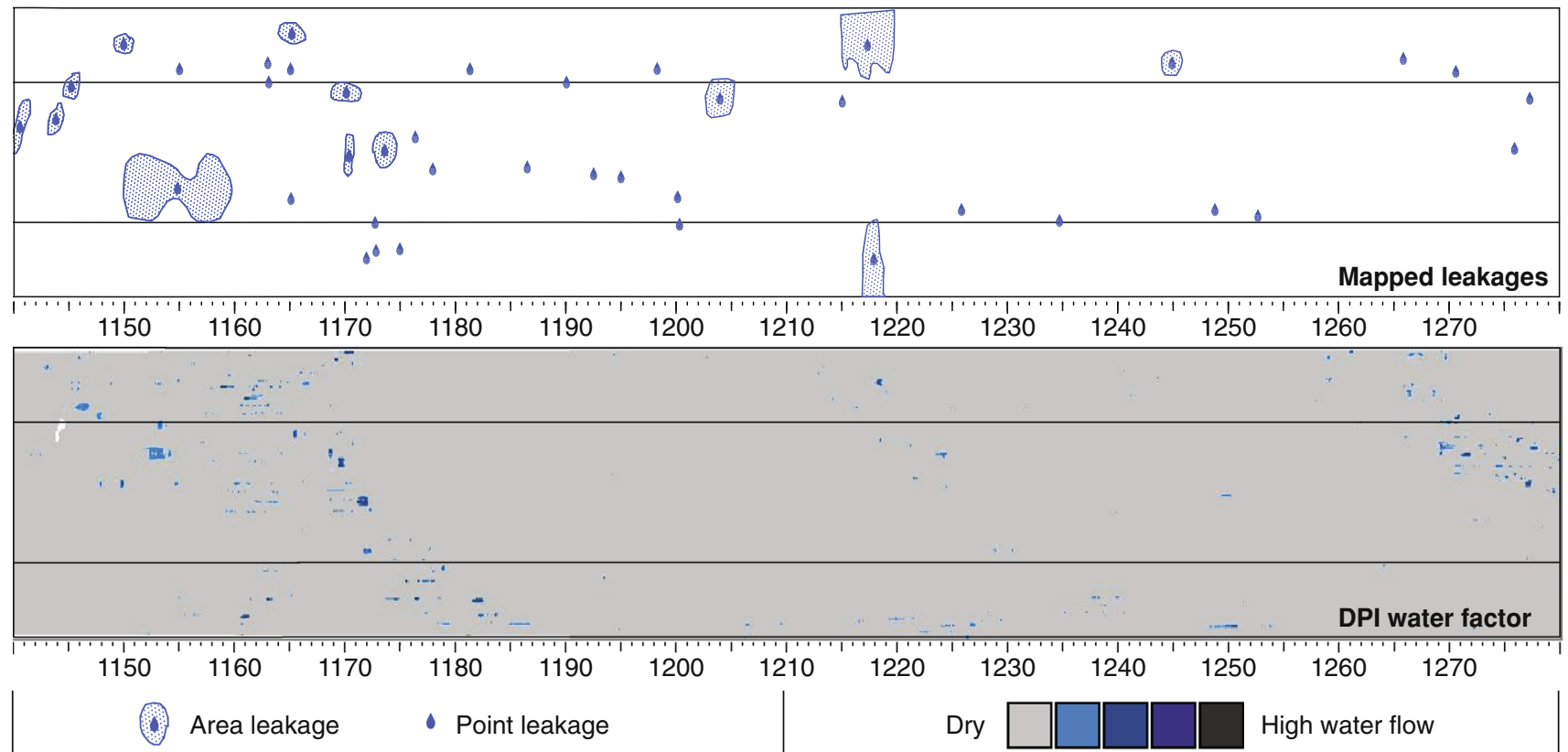

Fig. 15 Leakage mapping in the tunnel (upper part) and interpolated water factor from DPI (lower part)

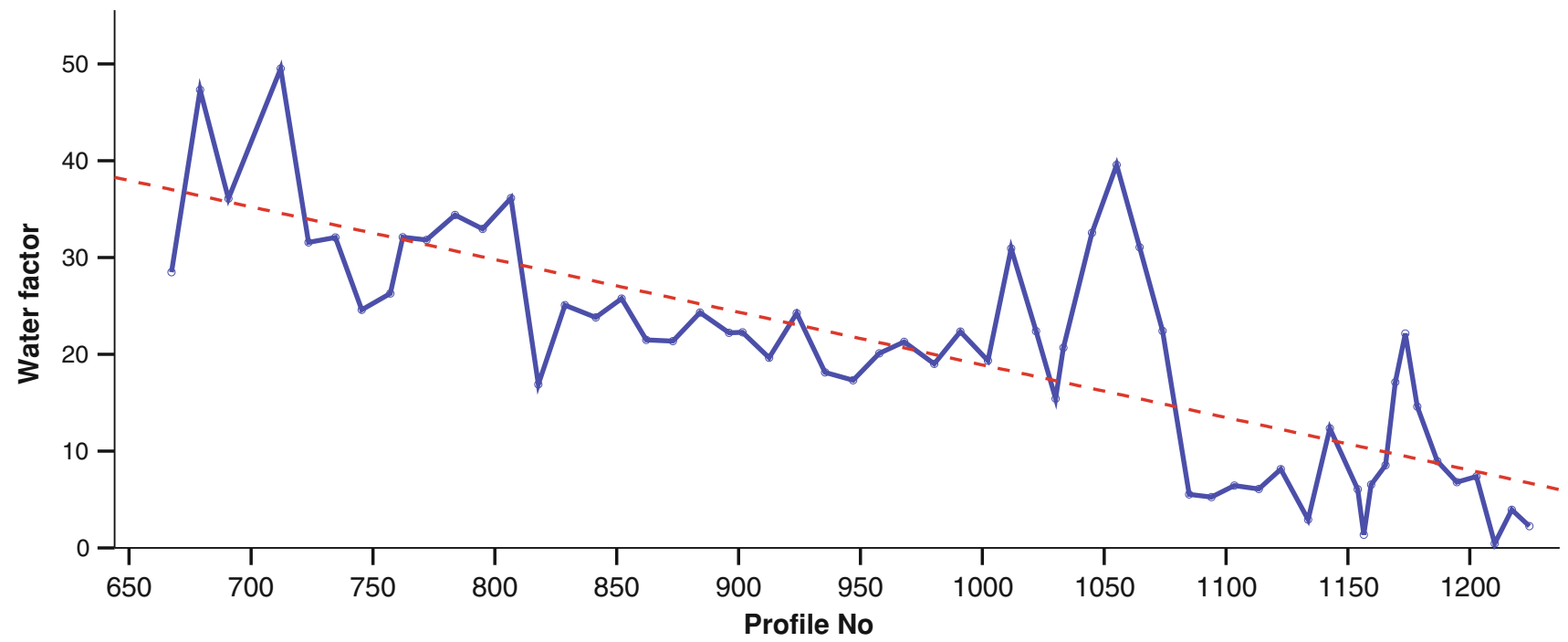

Fig. 16 Water factor for each section, along with the trend line used in the normalisation

\subsubsection{Grouting Volumes and the DPI Factors Water and Fracture}

The water factors for the respective sections are plotted in Fig. 16. A trend indicating that the water factor is increasing (seen in the excavation direction) from B1224 to the end of the tunnel (plotted with a red linear line) can be observed. Based on this trend line, the water factor has been normalised as described in Sect. 3.3.

In Figs. 17 and 18, the normalised water factor and the fracturing factor, respectively, and the grout volumes are plotted versus the profile number, and the main grouting parameters are given. The curves are simply fitted over each other to display possible connections between the parameters.

For Fig. 17, some sections seem to have fairly good correlation between the water factor and grout volumes, i.e. for B1203-B1154 and B1085-B991, the lines have a relatively good match. For B735-B667, the lines follow each other's paths, but have a scale difference. Also, an area with less fluctuation, B901-B862, may have a certain relationship. 




Fig. 17 Normalised water factor and grout volume for each section (grouting parameters at the top)

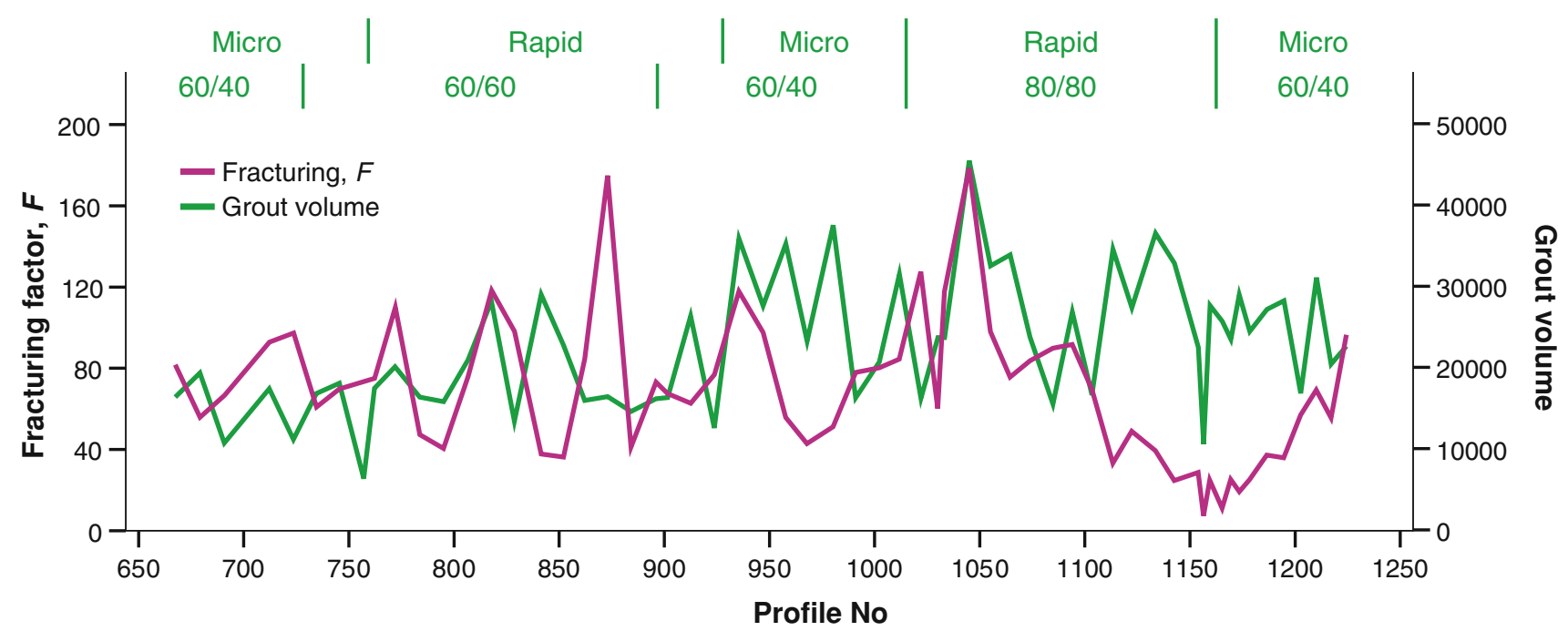

Fig. 18 Fracturing factor and grout volume for each section (grouting parameters at the top)

In Fig. 18, there are a few small areas that might indicate a relationship between the fracturing factor and grout volumes, i.e. B1055-B1033 and B784-B762.

\section{Discussion and Conclusions}

The pre-injection grouting that has been carried out for the Løren tunnel has given a water ingress which is lower than the pre-defined very strict restrictions, and, therefore, seems to have been successful. The reservation, however, has to be taken that this tunnel project is not quite completed, and there is a chance that the water ingress may increase when the groundwater level is back to normal.

As shown in Table 5, the grouting procedures were continuously modified during the construction process. To obtain a satisfactory grouting result, it is important to always evaluate the grouting procedures and observe the water leakages in the tunnel. At the Løren tunnel, the grouting procedures were adjusted to ensure satisfactory grout consumption and the possibility for the pressure to build up. Another adjustment for ensuring a satisfactory grouting result was the regulation of distances between curtains and grout hole lengths.

The experience from the Løren tunnel also emphasises that, during tunnelling, it is very important to observe the groundwater level and settlement of buildings for potential reconsideration of settlement calculations, need for extra waterproofing and/or need for permanent water injection. In the Løren case, based on such considerations, a planned watertight concrete lining and water infiltration system were found not to be required. The temporary infiltration 
boreholes in the tunnel were made permanent in case settlement on buildings should resume (but are not in use).

During the grouting operation, a large portion of the holes grouted with rapid cement was filled with approximately 521 of grout, while for the holes grouted with microcement, this same trend was not found (as shown in Figs. 14 and 15). This indicates that only the holes grouted with rapid cement are filled, and that there is no penetration into the rock mass. This illustrates that, in areas where water is expected, it should always be considered to switch to microcement in order to penetrate narrow water-bearing fractures.

It was also observed that a large portion of the holes grouted with micro-cement had almost no grout consumption (see Fig. 14). This may have been caused by micro-cement intrusion from nearby holes, with controlled curing, which cause the cement from nearby holes to harden and impede the grouting. Because of this, one should limit the quantities used when grouting with controlled curing. Another large portion of the holes in Fig. 14 range from very small grout consumption to about 601 . A possible cause of the low grout consumption in these cases may be explained by micro-cement without controlled curing which may have intruded from distant holes, partially hardened and interfered with the grout consumption.

As explained in Sect. 2.3, it was detected during construction that the cement accelerator pump fed a lower amount of grout than it was supposed to while performing controlled curing. The pump used was a rotation pump, which was not suitable for this application. It should, therefore, be emphasised that a piston pump, which can follow the strokes and flow of the cement pump, should be used when dealing with accelerator. This will ensure the right amount of accelerator for a successful controlled curing process.

The DPI and grout volumes in the Løren tunnel indicate that there may be a relationship between the grout volume and water factor if special geological features are taken into account.

There are many factors that may have had an influence on the grouting volumes and DPI factors. The main variables that may affect the results are as follows:

- Structural geology

- Rock properties

- Rock cover

- Rock stress

- Surrounding terrain/topography

- Type of grout and w/c

- End pressure

- Groundwater level

- The order in which the holes are drilled

- The order in which the holes are grouted

From approximately B990-B900, layers of bentonite rock have probably affected the grouting volumes. During grouting in this area, grout reached the surface on several occasions. The area above the tunnel had a lifting of the ground likely caused by the grouting and grout was observed as layers in the bedding plane direction during mapping. This indicates that hydraulic fracturing of the rock has caused new fractures that were not registered by the DPI. The peaks in the water parameter seen in Fig. 14 at B1173 and B1055 can be related to syenite intrusions (see Fig. 3). Peaks in grout consumption and an enlargement in water leakages can be observed in these areas. The fluctuations in the area from B720 to B760 may arise from a flat-lying syenite intrusion in the crown and it is also here seen an enlargement in the mapped water leakages.

The sequence in which the holes are drilled may affect the impact on the water factor. When a water-bearing fracture that crosses several holes is drilled through for the first time, this may drain the fracture and the impact on the following holes might be smaller. It is hard to estimate how much this affect the results, but since a relation can be seen between the mapped water leakages and the water factor, it is assumed that the water factor shows water where water is present.

The calculation of water and fracturing values (Eqs. 1 and 2) for the holes was created in such a way that it should take into account that a large single sample value should count more than a small value. This is because it is expected that a rock with a large single water or fracturing value would consume more grout than a small value, since it is expected that there is more water in the rock (larger crack) or a more distinct fracture. The increasing impacts, seen in Fig. 16, on the water factor through the tunnel may be a result of lower incoming water pressure on the tunnel rig caused by the increasing length of water pipes and the tunnel gradient which makes B667 32 m higher than B1224.

There are many factors that must be taken into account when evaluating the grout consumption and DPI results. For the study described in this paper, the interpretation of the figures consists of a subjective and visual comparison, where it may have been difficult to set cut-offs for where the data were correlating or not. Still, some quite significant relationships between the data for different areas have been found. In Figs. 14 and 15, the lines for the water factor, fracturing factor and grout volume are simply fitted over each other. Scale differences can be seen even with the normalised water data. This is not unexpected because of changes in overburden, grouting procedures etc. Still, it is possible to see a relationship between the variables if areas with the special geological conditions are taken into account. The area B735-B667 grouted with micro-cement in Fig. 14 seems to have a scale difference between grout volumes and the water factor, and similar grouting procedures (micro-cement and stop criterion 60/40 bar). This may be because of the increased percentages used for the controlled curing, which have limited the grout volumes. 
For future projects, a potentially very interesting use of the DPI during grouting would be to distinguish between the two basically different situations: (1) where there is water and (2) where it is not water. In areas with no water from the DPI, a grouting procedure with lower volumes and end pressure should be used to save time and cement. This might be achieved by using different grouting intensity number (GIN) values (Brantberger et al. 2000; Lombardi and Deere 1993) for different rock conditions based on the DPI factors.

Based on the experience from the Løren project and other Norwegian road tunnels, the MWD/DPI technology is believed to have a great potential for predicting water ingress and other rock mass parameters ahead of the tunnel face. The interpretation of data is, however, still uncertain, and more experience from tunnel projects is required in order for the technology to become a fully reliable, routine prediction tool. It is the intention that data collection for further refinement of this technology will be done at several road projects in the near future.

Acknowledgments The authors would like to thank the Norwegian Public Roads Administration for giving them the opportunity to write this article and Mr. Kari Bro, Mr. Patric Mårtenson and Mr. Greger Burman at Rockma Systems AB for providing the data and sharing their knowledge on the subject. In addition, thanks go to Ms. Inger Aakre, Mr. Arild Neby, Mr. Henki Ødegaard and Mr. Alf Kveen for the consultations during the writing process.

Open Access This article is distributed under the terms of the Creative Commons Attribution License which permits any use, distribution, and reproduction in any medium, provided the original author(s) and the source are credited.

\section{References}

Axelsson M, Gustafson G, Fransson A (2009) Stop mechanism for cementitious grouts at different water-to-cement ratios. Tunn Undergr Space Technol 24(4):390-397
Barstad M (2010) E 20 Lørentunnelen-Vanntett utstøpning av dyprenne i Lørentunnelen. The Norwegian Public Roads Administration, teknisk vurdering

Boge K (2010) Lørentunnelen. Vanntett utstøpning i dyprenne, AasJakobsen AS

Boge K (2012) E-mail on the current developments on groundwater levels and settlements in the Løren tunnel project

Brantberger M, Stille H, Eriksson M (2000) Controlling grout spreading in tunnel grouting - analyses and developments of the GIN-method. Tunn Undergr Space Technol 15(4):343-352

Carlsvärd C, Wallgren EE (2009) Utvärdering av MWD-teknikens möjligheter att identifiera vatternförande zoner vid Norra Länkenprojektet i Stockholm, Master. Kungliga Tekniska högskolan, Stockholm

Henriksen JP, Føyn T (2004) RV 150 Ring 3 Ulven-Sinsen-Forslag til innlekkasjekreav for tunnelene-konsekvenser for omgivelsene. Norconsult AS

Humstad T, Høien AH, Hoel JE, Kveen A (2012) Complete software overview of rock mass and support in Norwegian road tunnels. In: Eurock 2012, Stockholm, Sweden, May 2012

IBM (2010) IBM SPSS Statistics. IBM SPSS, version 19.0.0.1. IBM, Somers, NY

Iversen E (2011) Lørentunnelen-Longitudinal general geology section map

Lombardi G, Deere D (1993) Grouting design and control using the GIN-principle. Int Water Power Dam Constr 45(6):15-22

Rockma (2011) GPM+ Tunnel. GPM+. Rockma System AB, Skellefteå

Schunnesson H (1997) Drill process monitoring in percussive drilling for location of structural features, lithological boundaries and rock properties, and for drill productivity evaluation. Doctoral thesis, Luleå University of Technology, Luleå

Segui JB, Higgins M (2002) Blast design using measurement while drilling parameters. Fragblast 6(3-4):287-299

Smith B (2002) Improvements in blast fragmentation using measurement while drilling parameters. Fragblast 6(3-4):301-310

Valli J (2010) Investigation ahead of the tunnel face by use of a measurement-while-drilling system at Olkiluoto. Finland Working Report, vol 2010. Posiva Oy, Eurajoki

Vianova (2011) Novapoint Tunnel. Novapoint, 18.10 FP2c edn. Vianova Systems AS, Sandvika 